\title{
The Gashatan (late Paleocene) mammal fauna from Subeng, Inner Mongolia, China
}

Pieter Missiaen and Thierry Smith

Acta Palaeontologica Polonica 53 (3), 2008: 357-378 doi:http://dx.doi.org/10.4202/app.2008.0301

The Paleocene-Eocene boundary is of particular importance for the evolution of mammals and the poorly known Asian mammal faunas from this period have received much attention. The late Paleocene Subeng site in Inner Mongolia (China) has come under study only recently, and here we present the first complete description of its mammal fauna. Two new species are described, the neoplagiaulacid multituberculate Mesodmops tenuis sp. nov. and the praolestine nyctitheriid Bumbanius ningi sp. nov., representing stratigraphic range extensions of the respective genera into the Paleocene. Previously unknown parts of the dentition are described here for the eurymylid Eomylus bayanulanensis, the sarcodontid Hyracolestes ermineus, the cimolestid Tsaganius ambiguus, the carpolestid Subengius mengi, as well as the femur of the mesonychid Dissacus serratus. For most taxa, the new specimens from Subeng provide new phylogenetic and/or biostratigraphic information. We confirm the inclusion of Hyracolestes in the Sarcodontinae and elevate this group to the rank of family, the Sarcodontidae, separate from Micropternodontidae. In the case of Subengius mengi an updated cladistic analysis of carpolestids supports the hypothesis that Subengius is derived from an evolved Elphidotarsius -like ancestor in the early to middle Tiffanian of North America. A total of 17 species is identified, including well-known biostratigraphic markers for the late Paleocene Gashatan Asian Land Mammal Age such as Lambdopsalis bulla, Prionessus sp., Palaeostylops iturus, Pseudictops lophiodon, Tribosphenomys minutus, and Dissacus serratus. We propose that the Gashatan faunas are less endemic than previously thought, and result from a significant exchange with North American faunas from the late Paleocene.

Key words: Mammalia, "Insectivora”, Multituberculata, Glires, Carpolestidae, late Paleocene, Gashatan, Subeng, China.

Pieter Missiaen [pieter.missiaen@ugent.be], Aspirant of the Research Foundation-Flanders (FWO Vlaanderen), Ghent University, Research Unit Paleontology, Krijgslaan 281-S8, B-9000 Ghent, Belgium;

Thierry Smith [thierry.smith@naturalsciences.be], Royal Belgian Institute of Natural Sciences, Department of Paleontology, Rue Vautier 29, B-1000 Brussels, Belgium. 
This is an open-access article distributed under the terms of the Creative Commons Attribution License (for details please see creativecommons.org), which permits unrestricted use, distribution, and reproduction in any medium, provided the original author and source are credited.

For Full text $(1,090.6 \mathrm{kB})$ 